\title{
Article
}

\section{Drawing as a Way of Knowing: Visual Practices as the Route to Becoming Academic}

\section{Sandra Abegglen'}

Education, London Metropolitan University

Tom Burns

Centre for Professional \& Educational Development, London Metropolitan University

\section{Sandra Sinfield}

Centre for Professional \& Educational Development, London Metropolitan University

\begin{abstract}
This case study illustrates what happened when we took a playful approach in a first year undergraduate academic skills module and a graduate Facilitating Student Learning module asking our students to "draw to learn." We found that they not only enjoyed the challenges we set them, but also that they "blossomed" and approached their academic writing with more confidence and joy. Hence we argue for a more ludic approach to learning and teaching in Higher Education to enable Widening Participation students and their tutors to become the academic writers they want to be. In particular "blind drawing" seems to be a powerful tool for diminishing the fear of failure and for fostering deep understanding as well as self-confidence.
\end{abstract}


Volume 28, 2018

http://journals.sfu.ca/cjsdw

\section{Introduction}

"Drawing provides a level of interpretation that is distinctly human and encourages understanding" (Corti cited in Hernly, 2016, p. 130).

Our institution, London Metropolitan University, is a post-19922 inner city university situated near the heart of London (United Kingdom) and as such recruits students from countries across the world ${ }^{3}$. This means, our student body is made up of almost fifty per cent non-traditional students (Blagburn \& Cloutterbuck, 2011), that is, our students are typically mature (over 21), from working class, Black, and Minority Ethnic Communities. They are also often the first ones in their families to enter Higher Education (HE). In the United Kingdom (UK) these students are known as Widening Participation students. They are considered to be non-traditional, coming from families without a history of university education (Sinfield, Burns \& Holley, 2004) and therefore with no or little experience of HE and its demands.

We, the authors of this paper, teach undergraduate and graduate courses at London Metropolitan University. As lecturers, and education and learning developers, we encourage students and lecturing staff to develop their pedagogic skills and practice by harnessing ludic spaces for empowerment (Sinfield, Burns \& Abegglen, forthcoming). In our first year undergraduate module, Becoming an Educationist (Becoming), the student cohort is as near to $100 \%$ non-traditional as can be. This means that the majority of students in this module as well as having to engage with paid work alongside their degree programme ${ }^{4}$, typically also have caring responsibilities within the home. Their time in and for the University is often limited, which makes adjusting to the demands of university and university life particularly challenging. In our graduate module, Facilitating Student Learning, the student cohort is made up of University lecturers aiming to enhance their teaching practice through Continuing Professional Development. They can complete Facilitating Student Learning as part of a Postgraduate Certificate of Learning and Teaching in Higher Education or masters qualification, Learning and Teaching in Higher Education. The ludic practice, and visual and 
Volume 28, 2018

http://journals.sfu.ca/cjsdw

multimodal strategies utilised in the Facilitating Student Learning module were drawn from and modelled on the practices that we first employed in the Becoming module.

This paper explores how we used playful and visual strategies to empower our students. With our Widening Participation undergraduate students, this meant enabling them to become the successful students and academic writers that they want to be. For our graduate Facilitating Student Learning students, as well as developing their academic and writing skills practice, this meant enabling them to become the successful pedagogues that they want to be, ready to develop the writing skills of their own students.

\section{The Context: Our Approach to Learning and Teaching}

Becoming is a thirty-week core module that all Education Studies undergraduate students must take in their first year. It is designed to orientate students into academia and start the development of their emergent graduate identities. Assessment is spaced across the thirty weeks and includes: one, a portfolio of evidence demonstrating engagement in three learning projects; two, a small-scale qualitative research project report, where students investigate some aspect of university study; and finally a reflective essay. The graduate Facilitating Student Learning module is semester-long and focuses on the theory and practice of emancipatory (Nouri \& Sajjadi, 2014) university pedagogy. The assessment in this module includes a portfolio demonstrating: engagement with relevant literature; critical reflection on one's own practice; and meta-reflection on the Facilitating Student Learning module itself. Ironically, in both the undergraduate and the graduate modules the students tend to say that they are "not academic" and they cannot write (or at least that they cannot teach others how to write); nor do they think they are creative. In both cases we use play and a playful or ludic approach to de-stabilise notions of what education itself is and could be, and to foster creativity as a fundamental underpinning to academic literacies development and to pedagogy.

Our emphasis on play is not "dumbed down" learning, for as Parr (2014, para. 1) states: "Play is serious business." Indeed, our use of the ludic is recognition of the many challenges 
Volume 28, 2018

http://journals.sfu.ca/cjsdw

that our students face, for most of our undergraduates Higher Education is a byzantine, exclusionary space in which they feel uncomfortably exposed. We argue that a playful approach to academic writing not only facilitates the freedom to experiment and question (Huizinga, 1949), but also creates opportunities for the crossing of the important academic threshold of phronesis, that is, deliberation with no pre-determined outcome (Meyer \& Land, 2006; Molinari, 2017). Based on this assumption we argue that we need play in Higher Education and in our modules, because "It is in playing and only in playing that the individual child or adult is able to be creative and to use the whole personality, and it is only in being creative that the individual discovers the self" (Winnicott 1971, p. 54). Thus we developed playful and visual practices (viz. http://about.brighton.ac.uk/visuallearning/) as a means of developing academic literacies and the writing self. Probably the most important point of this for us is the unleashing of the creative potential in our students, a creativity that once harnessed develops self-efficacy and self-belief. This builds our students' confidence in themselves as emergent academic writers and/or as teachers of academic writing.

\section{Playful Writing: Insights into our Practice}

Our first play-enabled writing activity is timetabled early in the academic year (week three or four). We ask each undergraduate student to reflect on their experience so far: what they experienced when they first entered the building or looked for their classroom, what that first lecture felt like. We ask them to consider all those myriad feelings and to construct a collage to encapsulate or reflect all those, perhaps, contradictory feelings. After creating their collage, students carefully examine it and use that to generate a "free write" (Elbow, 1998) on their experiences. The aim of this activity is to "ease" students into Higher Education, their course and the module as well as into the demands of academic writing. In the graduate course, we ask participants to produce two collages in the first week of their module, one that encapsulates who they are and another that best represents their pedagogic approach. This seeds thought, dialogue and then reflective writing. Importantly, 
Volume 28, 2018

http://journals.sfu.ca/cjsdw

for the lecturers this activity helps to de-stabilise taken-for-granted notions of what encompasses teaching, and their role as empowering academics.

Another activity, which typically follows the first one, is to encourage our students to draw to learn. We are interested in drawing as a way of thinking differently about or reconfiguring information and, more prosaically, as a way of building mnemonic triggers in student notes. However, when we announced that they had to draw, every students' head dropped with despair. It appeared that our students, under- and postgraduate alike, found the thought of drawing in an academic setting to be intimidating. On investigation, we discovered that most of them had set aside drawing when they left kindergarten and now internalised the idea that they "can't draw." Whilst we knew that our students struggled with academia and with formal academic writing (Abegglen, Burns \& Sinfield., 2015), we were surprised to see that they struggled with the notion of themselves as creative people and they doubted the legitimacy of creative practices in academic spaces. Thus to introduce drawing, we first had to de-stabilise the notion of drawing itself; instead of asking students to produce a Da Vinci-esque representation of something they observed, we ask them to "blind draw" (viz. http://www.drawingandpaintinglessons.com/Drawing-Lessons/BlindContour-Line-Drawing-1.cfm). That is, when asking our Becoming students to draw, we encourage them to look closely at a neighbour and to draw them while keeping their eyes on their subjects and not looking at the paper they are drawing upon. We want them to move the pen or pencil as much as possible, trying not to remove the implement from the paper but going back and forth, making many marks. We reassure them that it is totally expected and okay if they cannot draw an accurate representation. Instead they will produce a picture that captures a poetic "something," the essence or the spirit of the person that they are drawing. In this way, they discover, they see for themselves, that drawing, mark making, is not necessarily something to be afraid of but rather is something that can be explored, deployed and even enjoyed.

The pictures produced normally have some form of "energy" whilst having none of the traditional qualities of realistic art. ${ }^{5}$ We love these pictures and have some framed in our office to remind us of what happens when you give students permission to play and 
Volume 28, 2018

http://journals.sfu.ca/cjsdw

experiment, to be more creative in their learning (Crème, 2003; Jackson, 2013). We find that the laughter created by this activity allows our students to feel differently about their drawing and themselves, and perhaps not to fear "failure" quite as much. This is permission to give mark making a "go," to play with it and to experience what happens when you do. This is scaffolding dialogic, experimental, and critical thinking and writing.

With the graduate students, we utilise a more conceptual form of pre-writing drawing, where we ask them to produce "rich" pictures to illustrate their thoughts about, say, the curriculum or assessment or group work, or to think through ideas about academic writing. Our graduates, lecturers supposedly used to academic writing, react often in a very similar way to the drawing task as our undergraduates. They also do not like the idea of exposing themselves in front of others. Ironically, they often describe themselves in the same terms as our undergraduate students: "I am not creative." Or "I am not academic." There is a vulnerability that they experience that we are, in some ways, encouraging them to work through such that they can better facilitate that development in their own students.

From blind drawing and "rich" pictures, both undergraduate and graduate students move on to analyse their drawings to see what underlying assumptions they reveal: the ontology and epistemology of their work. One example of this is where after a session on research methods, we asked the students to draw epistemology itself, and then analyse their own drawings. In one drawing a student had depicted books, that represented the more traditional notion of epistemic knowledge coming from the literature, but she had also drawn people speaking, a globe and a microscope. Discussing her own picture with others revealed deeper understanding of epistemology than she had first realised herself, and in the process utilised the language of academic discourse. Such encounters enable our undergraduates to enter their epistemic communities and take more control of themselves as students, which also facilitates their writing confidence.

With the graduate lecturers, we encourage them to tease out the threshold concepts of teaching, learning, and of academic writing; within the process we want them to take more control of themselves as staff who are empowering their students to become active learners and powerful academic writers. For example, we also ask our graduate-student writers to 
Volume 28, 2018

http://journals.sfu.ca/cjsdw

draw their notes and annotate the texts that they are reading, typically first as enlarged scrolls-articles or chapters blown up to a large print size with the pages stuck together to form not a paginated and gated text, but an unrollable, open text scroll (viz. http://www.textmapping.org/scrolls.html), as a way of developing their writing. They explore their ideas through a mixture of pictures and writing with the aim of linking their ideas, analysing content and creating deeper understanding. To scaffold this, we put black sugar paper over and coloured chalk on the tables around which they discuss topics. By now, undergraduate and graduate students alike find themselves picking up the chalk and sketching out their ideas on the sugar paper, naturally. Drawings emerge on the tabletops as part of the dialogic learning process and students find that they have produced "posters" with which to illustrate their thinking and explain their ideas for writing.

Building on these mark making and pre-writing activities we ask undergraduates students to produce a "digital me," some form of animation or multimodal representation that reveals who they are or their thoughts about digitally enabled study; whilst the graduate students are also asked to produce a multimodal artefact, not to represent themselves, but as an alternative to a group presentation (where students stand in front of the class presenting an assessment or feedback-based topic to their peers). In each case, as with formal academic writing, the participants are learning about meaning making, message construction and ideas representation; they edit and revise their messages on the way to producing artefacts and animations of which they are proud and of which they take ownership.

Most students undertaking our modules do not realise at first that these drawing and digital challenges are not only developing their self-efficacy and self-confidence, they are also aimed at academic writing and the development of complex academic literacies: reading, note making and criticality—but also drawing and blogging as and for learning, and digital and writing confidence and fluency. As they have made animations and videos and built 3D artefacts, they have developed their understanding of particular genres and familiarised themselves with the syntax and the detailed minutiae of message construction within those genres. About a third of the way into the modules we introduce meta- 
Volume 28, 2018

http://journals.sfu.ca/cjsdw

reflective processes where we tease out more overtly the relationship between these meaning makings and formal academic writing. We explore writing as process and the genre conventions of the essay or the research report; running dedicated workshops where students write and peer review their writing in class. By now, self-confidence has grown and the students report back that they are able to enjoy this opportunity to write and reflect on their writing.

\section{Feedback and Evaluation}

Feedback collected formally and informally suggests that both the under- and postgraduate students enjoyed the creative tasks that we wove through both modules, Becoming and Facilitating Student Learning, and recognised that these tasks had developed their academic skills (undergraduates) and their teaching skills (graduates), as well as the writing skills of both groups. Our evaluation of both modules included not only assessing the in-class atmosphere, the reflective learning that the students represent in their learning logs, produced as blogs or padlets (viz. https://en-gb.padlet.com/), but also grading their final research reports and meta-reflective essays.

The graduate students stated that the module and the team were "inspirational" and valued our consistently positive approach and good humour, which "made a real difference to my self-perception as a novice teacher."6 Whilst the overall workload proved a struggle, the engaging nature of the workshops and the choice offered to personalise assessments and assessment modes allowed a freedom and produced an "excellent learning environment."

With the graduate students, we also saw that the introduction of this more creative curriculum has coincided with a rise in the number of distinctions awarded for the postgraduate writing. A distinction in the UK is a mark of $70 \%$ and above and is typically awarded to graduate students who demonstrate strong grasp of theory, concepts and context with perceptive treatment of material and good integration of a range of relevant literature and data. The work has to be logically structured and the higher distinctions are 
Volume 28, 2018

http://journals.sfu.ca/cjsdw

awarded for originality or insight, sophisticated theorisation and innovative conceptualisation. Moreover, the External Examiner for that module concluded that the final meta-reflective essay was now the "capstone" of the course rather than a summary of the course itself (London Metropolitan University, 2017), which we feel endorses our playful approach to teaching the course and the way that this scaffolded the participants' writing.

This positive finding with graduate students is supported by the results of a small-scale study undertaken by and with first year undergraduate students on the Becoming module using Image Mediated Dialogue (Palus \& Drath, 2001). The Becoming students emphasised that the creative nature of the course and the challenging activities helped to create a sense of unity and achievement. In addition, they felt the activities increased their enjoyment, which, in turn, helped them to succeed. They all felt that this playful module fostered selfdevelopment, helping them to build confidence and become who they want to be. One outcome of the Becoming module's approach to academic writing was an undergraduate student who, arguably, powerfully re-framed and owned, "academic writing" itself, taking a more multimodal and diverse approach to his final portfolio. This student presented his final portfolio as a shoebox containing a running shoe, postcards and a t-shirt, all embellished with graphic novel style illustrations that reflected his deep learning on and enjoyment of the module.

Another unexpected consequence of our playful and visual approach to academic study and writing was that one student conducted her first year qualitative research project on students and their reasons for resisting drawing. She confirmed that our students felt as intimidated by drawing as by academic writing. If being required "to draw" (note the punitive overtones) they needed reassurance, they needed drawing to be supported, encouraged, and scaffolded and they needed to develop self-efficacy, a sense that in this troublesome arena they could succeed. Our student's solution was to design a space on her blog to reassure other students that they did not have to be able to draw to make visual notes and she designed a short tutorial designed to teach other students how to make visual 
Volume 28, 2018

http://journals.sfu.ca/cjsdw

notes (viz. https://noblechloe.wordpress.com/first-year-learning-logs/visual-notes/whosays-you-need-to-be-able-to-draw-to-make-visual-notes/).

\section{Conclusions}

To conclude, we have used playful and visual exercises in our teaching to actively tackle the fear of writing and a fear of failure in academia and to build creativity and self-efficacy in our students. We have also encouraged a variety of mark making activities, physical and multimodal, to foreground learning processes and foster academic writing. And we have seen that play has fostered academic and personal self-confidence and the development of formal writing skills. This in and of itself has been empowering and emancipatory for our students. It has led us to completely re-frame what had been previously termed a "study skills" or "academic literacies" module (Lea \& Street, 1998) and to move away from a notion of Widening Participation students needing to bridge the gap between their deficit selves and academia. Our students are, and deserve and need to be, welcomed into our modules as the valuable and strong and capable human beings that they are. They need to be invited on the creative and exploratory journey of becoming the academic writers they want to be. Similarly, our graduate students are no longer taught (just) theoretical approaches to teaching and to teaching our students; but rather experience for themselves the issues and pressures associated with academic study and academic writing as they reflect on their own playful learning and writing experiences.

Playful practice is, for us, where theory and practice collide: our students are typically never represented as capable nor celebrated for the skills they bring and the risks they take. Our under- and postgraduate students all spoke of their concerns about the pressure to muster all that messy learning into a piece of fluent and well-structured academic writing (and then teach others how to do it). Thus in our modules "play" not "skills" became the process that smoothes out the reductive, transactional striations of the formal education through which all of our students have passed. We challenged all our students and asked them to "play." However, this did not just happen, this was not an easy pedagogic choice: we 
Volume 28, 2018

http://journals.sfu.ca/cjsdw

had to ease our students into an awareness of their own creativity and connect that to the creativity necessary for successful study and for successful academic writing.

\section{Endnotes}

1. Correspondence may be addressed to s.abegglen@londonmet.ac.uk.

2. In 1992 UK Polytechnics were offered the opportunity to become universities in their own right. These are now called post-1992 institutions.

3. We come 18th in the QS Top Universities (2016) rankings for the international diversity of its student body.

4. Education Studies (BA Hons) is a three-year full time honours degree that offers 120 credits per year and where students have to undertake a Dissertation in the third year (viz. http://www.londonmet.ac.uk/courses/undergraduate/education-studies---ba-hons/).

5. Included here are two blind drawings from a recent draw to learn workshop: one is of a student (Figure 2) and one is of Tom (Figure 1), one of the authors of this paper.

6. As cited in the Facilitating Student Learning Module Monitoring Log 2016/17. 
Volume 28, 2018

http://journals.sfu.ca/cjsdw

\section{Illustrations}

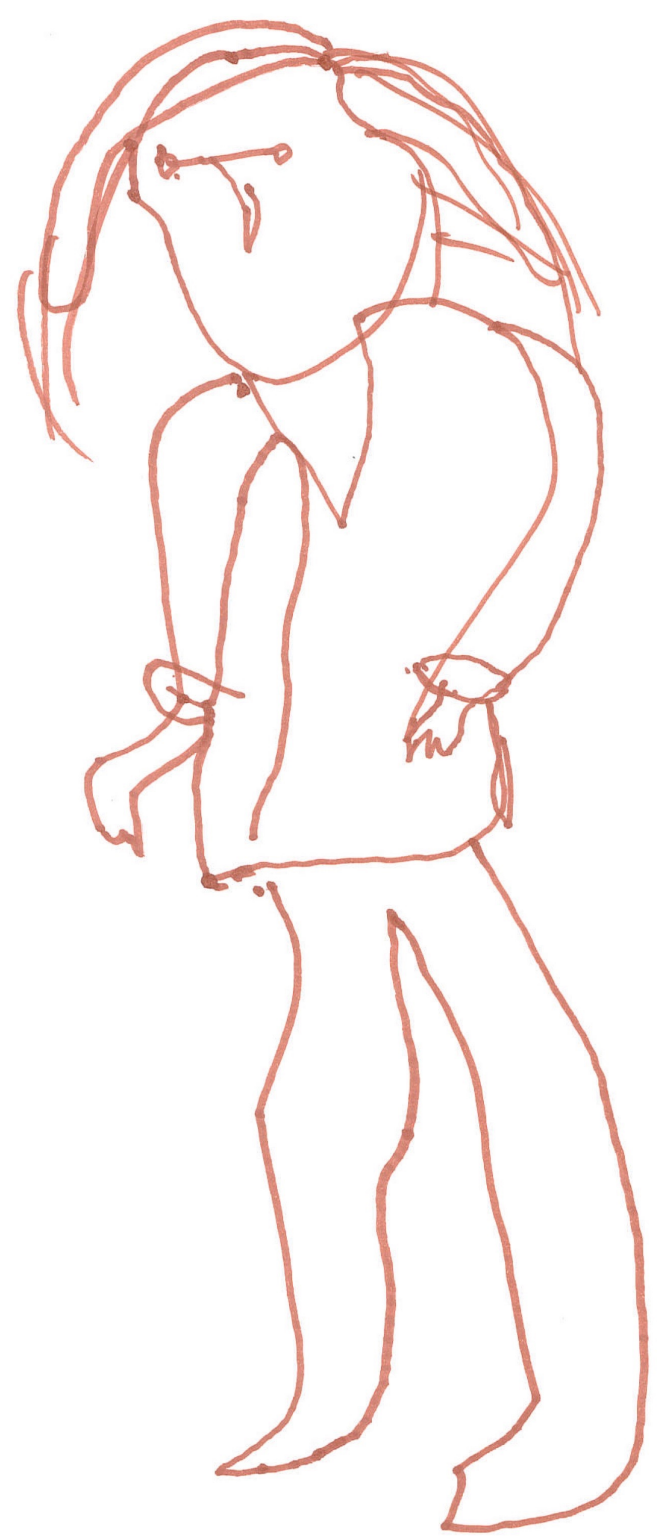

Figure 1: Blind Drawing 1. Anon. (2014). Tom. (c) Abegglen, Burns \& Sinfield. 


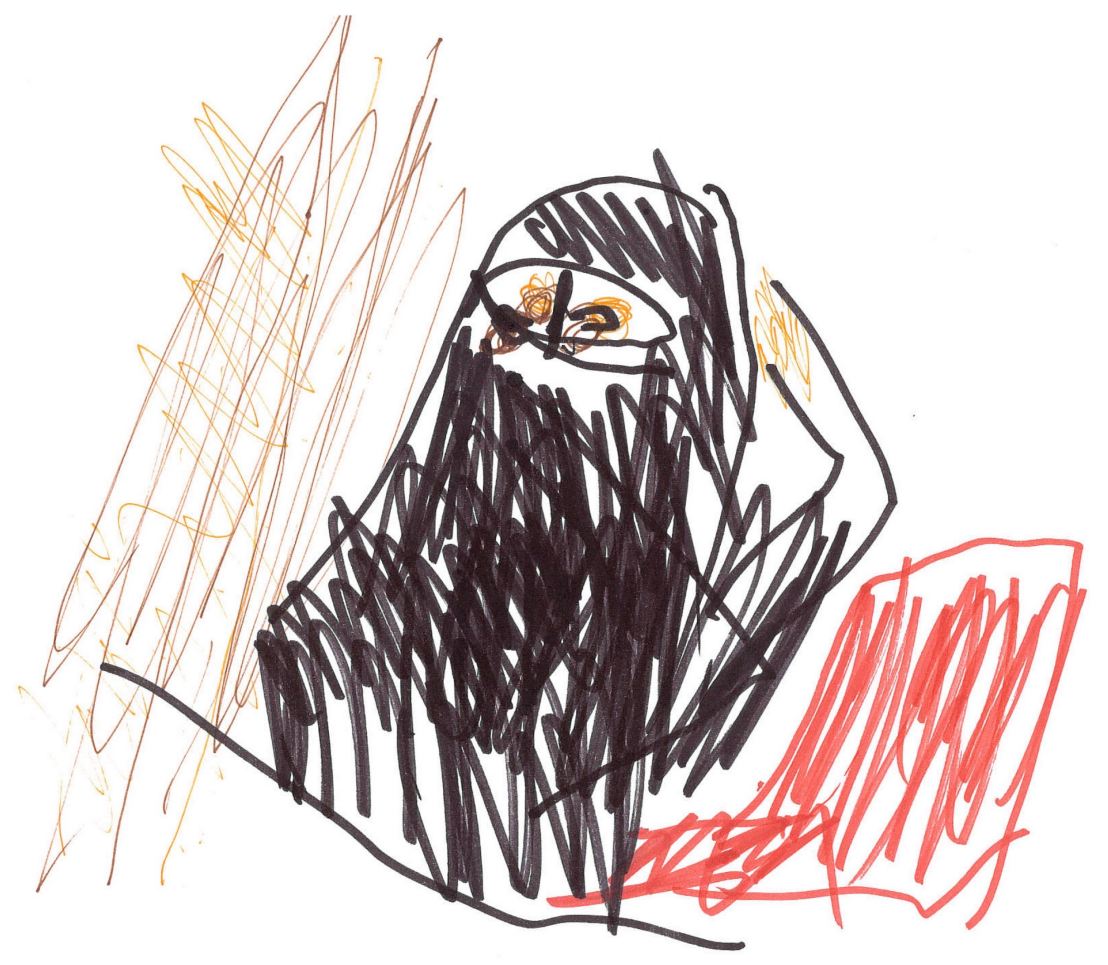

Figure 2: Blind Drawing 2. Anon. (2014). Nesim. (c) Abegglen, Burns \& Sinfield

\section{References}

Abegglen, S., Burns, T. \& Sinfield, S. (2015). Voices from the margins: Narratives of learning development in a digital age. Journal of Educational Innovation, Partnership and Change, 1(1). doi: $10.21100 /$ jeipc.v1i1.148

Blagburn, P. \& Cloutterbuck, S. (2011). A multi-disciplinary approach to retention and drop out: A response to institutional concerns. Paper for Access and Retention: Experiences of 
Volume 28, 2018

http://journals.sfu.ca/cjsdw

Non-traditional Learners in Higher Education. Retrieved from

http://www.dsw.edu.pl/fileadmin/www-ranlhe/files/Blagburn_et_al.pdf

Crème, P. (2003). Why can't we allow students to be more creative? Teaching in Higher

Education, 8(2), 273-277. doi: 10.1080/1356251032000052492

Elbow, P. (1998). Writing without teachers (2nd Ed.). New York: Oxford University Press.

Hernly, K. (2016). Drawing the real and the unknown: A look at a project by Gemma

Anderson. Drawing: Research, Theory, Practice, 1(1), 125-132. doi:

10.1386/drtp.1.1.125_7

Huizinga, J. (1949). Homo ludens: A study of the play-element in culture. London: Routledge \& Kegan Paul.

Jackson, N. (2013). Tackling the wicked problem of creativity in Higher Education. Lifewide

Education Community UK. Retrieved from

http://www.normanjackson.co.uk/uploads/1/0/8/4/10842717/_tackling_the_wicked_p roblem.pdf

Lea, M.R. \& Street, B.V. (1998). Student writing in higher education: An academic literacies approach. Studies in Higher Education, 23(2), 157-172. doi:

$\underline{10.1080 / 03075079812331380364}$

London Metropolitan University, (2017, November 30). Perfomance Enhancement Meeting. London: London Metropolitan University. [Minutes].

Meyer, J.H.F., \& Land, R. (Eds). (2006). Overcoming barriers to student understanding:

Threshold concepts and troublesome knowledge. London: Routledge.

Molinari, J. (2017, June). What makes our writing academic? reGenring17 Conference, Nottingham on Trent University, United Kingdom. [Presentation].

Nouri, A. \& Sajjadi, S.M. (2014). Emancipatory pedagogy in practice: Aims, principles and curriculum orientation. The International Journal of Critical Pedagogy, 5(2), 76-87.

Palus, C.J. \& Drath, W.H. (2001). Putting something in the middle: An approach to dialogue. Reflections, 3(2), 28-39. Retrived from http://www.ccl-explorer.org/wpcontent/uploads/2012/01/Mediated_dialogue_Palus-and-Drath1.pdf 
Volume 28, 2018

http://journals.sfu.ca/cjsdw

Parr, R. (2014, May). The importance of play. Times Higher Education. Retrieved from https://www.timeshighereducation.com/features/the-importance-of-

play/2012937.article

QS Top Universities (2016). Worldwide university rankings, guides \& events. Retrieved from http://www.topuniversities.com/qs-world-university-rankings

Sinfield, S., Burns, T. \& Abegglen, S. (forthcoming). Becoming playful: The power of a ludic module, in A., James \& C., Nerantzi, Eds, The power of play in higher education. London: Palgrave Macmillan.

Sinfield, S., Burns, T. \& Holley, D. (2004). Outsiders looking in or insiders looking out? Widening participation in a post-1992 university, in J. Satterthwaite \& E. Atkinson, Eds, The disciplining of education: New languages of power and resistance, (137-152). Stoke on Trent: Trentham Books.

Winnicott, D.W. (1971). Playing and reality. London: Tavist. 